\title{
28 Research Square \\ Shedding light on how ER stressors can be used to treat disease
}

Paula Lindner

Søren Brøgger Christensen

Poul Nissen

Jesper Vuust Møllerd

Nikolai Engedal

\section{Video Byte}

Keywords: thapsigargin, endoplasmic reticulum, calcium, ER stress, unfolded protein response, cancer, treatment

Posted Date: October 29th, 2020

DOl: https://doi.org/10.21203/rs.3.rs-100313/v1

License: (c) (i) This work is licensed under a Creative Commons Attribution 4.0 International License. Read Full License 


\section{Abstract}

The endoplasmic reticulum (ER) ensures that newly synthesized proteins in a cell are properly folded. But when the number of new proteins exceeds the ER's capacity to fold them, ER stress can occur and the "unfolded protein response" (UPR) is triggered to help return the cell back to normal. If the UPR can't restore this balance, the cell dies. Triggering cell death by ER stress via the UPR is one way to treat diseases such as cancer, but we must fully understand the signaling mechanisms involved to design drugs to effectively trigger the UPR. ER stressors such as thapsigargin can induce UPR-mediated cell death, but the detailed mechanisms are unclear. In a recent study, researchers sought to better understand how ER stressors work. They analyzed molecular changes in human prostate and colon cancer cell lines exposed to thapsigargin or its analogs. Their results demonstrated which UPR components and cell death processes are required for an ER stressor to effectively kill a cell. Although additional work is needed to determine the generality of these findings. The results of this study provide new insights into the induction of cell death by ER stressors, and suggest that thapsigargin could serve as a basis for new drugs designed for targeted killing of cancer cells 